УДК [581.93:581.526.3:556.53](282.243.705)

Погорєлова М.С.: https://orcid.org/0000-0001-9818-8088

\title{
СТРУКТУРА ВОДНОЇ ФЛОРИ ВОДОТОКІВ КІЛІЙСЬКОЇ ДЕЛЬТИ ДУНАЮ
}

\author{
(C) Погорєлова М.C. \\ Інститут гідробіології НАН України, м. Київ \\ chertkovams1988@gmail.com \\ https://doi.org/10.34142/2708-5848.2020.22.2.05
}

\begin{abstract}
Здійснено структурно-порівняльний аналіз таксономічної, екологічної та географічної структури флори водотоків Кілійської дельти Дунаю. Конспект досліджуваної флори нараховує 41 вид з 27 родів, 21 родин, 16 порядків, 4 класів та 3 відділів. Проаналізовано таксономічний склад основних таксономічних одиниць, та співвідношення між ними: відділ Magnoliophyta переважає (90.2 \%), в межах якого домінує клас Liliopsida (83.8\%). До перших трьох провідних родин належать Potamogetonaceae, Lemnaceae та Hydrocharitaceae, які складають 36.6\% від загальної кількості флори У складі флори представлені шість видів адвентивної фракції - один археофіт (Acorus calamus L.) і п’ять кенофітів (Azolla caroliniana Willd., Azolla filiculoides Lamark., Elodea canadensis Michx., Sagittaria latifolia Willd., Vallisneria spiralis L.). Рідкісні рослини, що охороняються на території всієї України у водотоках КДД представлені трьома видами: Salvinia natans (L.) All., Nymphoides peltata (S.G.Gmel.) Kuntze та Trapa natans L. s.l. До регіонально рідкісних видів, які охороняються тільки на території Одеської області належать ще п'ять видів: Lemna gibba L. (вразливий), Bolboschoenus maritimus (L.) Palla (недостатньо вивчений), Najas marina L. (недостатньо вивчений), Potamogeton gramineus L. ( недостатньо вивчений), Typha grossheimii Pobed. ( недостатньо вивчений).

Екологічна структура представлена трьома екотипами, серед яких найбільше гідрофітів - 23 (56.1 \%). В ньому переважає екогрупа вільно плаваючі на поверхні води (22\%). Співвідношення екотипів гідрофіти, гелофіти, гігрогелофіти складає 4:2:1.

В хорологічному спектрі зональних географічних груп найбільша кількість видів відноситься до плюризональної групи - 18 видів (44\%). Серед регіональних груп переважає циркумполярне поширення, його мають також 18 видів (44\%). За характером розміщення ареалів видів в океанічних або внутрішніх водоймах найбільша кількість видів належить індиферентній до континентальності та океанічності групі. Подібний спектр є характерним для водної флори України та для інших флор різних регіонів помірної зони Євразії.
\end{abstract}

Ключові слова: таксономічна, екологічна, географічна структура, вищі водні рослини, водотоки, Кілійська дельта Дунаю.

Водні та прибережно-водні рослини $є$ важливим компонентом водних екосистем, оскільки відіграють суттєву роль у їх функціонуванні, створюють біогеоценотичне середовище для пов'язаних 3 ними гідробіонтів, а також виступають місцями для гніздування та кормовими угіддями для птахів. Їх структурні характеристики можуть слугувати індикаторами стану водної флори на досліджуваних об'єктах [3], а застосування систематичного, екологічного та географічного аналізу - дозволяє виявляти специфічні риси флори певних об'єктів або територій, та їх подібність між собою [24]. На території зовнішньої (морської) Кілійської дельти Дунаю (КДД) розташована українська частина білатерального Дунайського біосферного заповідника, створеного для захисту унікальних біоценозів дельти. Це $\epsilon$ наймолодша та найбільш динамічна частина дельти Дунаю. Дослідження цієї території представляє значний науковий інтерес. Структурні флористичні аналізи проводилися для всієї території української частини дельти Дунаю $[1,8-9$, 21] однак їі головні артерії - водотоки дуже мало досліджені[4]. Метою роботи було визначення структурних характеристик вищих водних рослин (ВВР) в Кілійській дельті Дунаю та проведення їх порівняльного аналізу з іншими водними флорами. 


\section{МАТЕРІАЛИ І МЕТОДИ}

Дослідження проведені протягом 2013-2017 років, загалом було зроблено 214 описів макрофітів водотоків зовнішньої (морської) Кілійської дельти Дунаю (КДД). Дослідження проводилися під час їх найбільш інтенсивного розвитку - влітку та на початку осені. Описи здійснювалися згідно стандартних європейських методик [11] на основних рукавах Кілійської дельти Дунаю (Анкудинів, Бистрий, Білгородський, Восточний, Гнеушів, Отножний, Очаківський, Прорва, Страростамбульсь-кий), природних єриках, що з'єднують водні об'єкти між собою та штучних єриках, які розташовані на території міста Вилково.

У роботі назви видів та обсяг родин подано за «Vascular plants of Ukraine. A nomenclatural checklist» [15]. Інформація про рідкісні рослини надана згідно офіційних переліків регіонально рідкісних рослин адміністративних територій України [16].

\section{РЕЗУЛЬТАТИ}

\section{Таксономічна структура}

За результатами власних досліджень склад вищих водних рослин водотоків Кілійської дельти Дунаю налічує 41 вид 327 родів, 21 родин, 16 порядків, 4 класів та 3 відділів. Таксономічна формула, яка виражає відношення кількості надвидових таксонів у даній флорі у послідовності - відділ: клас:
Екологічна класифікація виконана згідно Папченкова В.Г, в основу їі покладені такі ознаки, як ступінь зв'язку 3 повітряним середовищем та грунтом i висота пагонів повітряно-водних рослин. Під водною флорою ми розуміємо тільки перші три типи : гідрофіти, гелофіти та гігрогелофіти, що співпадає з позицією багатьох учених [1718]. Екологічні групи за відношенням до коливання рівня води, вмісту кисню, кількості солей та рівні первинної продукції надані за Карпова Г., Зуб Л., Мельничук В., Проців Г.[12].

Для аналізу географічної структури був використаний метод просторової тримірної системи координат Г. Мейзеля зі співавторами [13], приналежність виду до певної географічної групи визначалася за роботою Дубини Д.В., Шеляга-Сосонко Ю. Р [7].

Таксономічна структура водної флори КДД

\begin{tabular}{|c|c|c|c|}
\hline Відділ & Клас & Порядок & Кількість видів \\
\hline \multirow{9}{*}{ Magnoliophyta } & \multirow{8}{*}{ Liliopsida } & Najadales & 7 \\
\hline & & Arales & 6 \\
\hline & & Alismatales & 4 \\
\hline & & Hydrocharitales & 4 \\
\hline & & Typhales & 4 \\
\hline & & Cyperales & 3 \\
\hline & & Poales & 2 \\
\hline & & Iridales & 1 \\
\hline & Magnoliopsida & Araliales & 1 \\
\hline
\end{tabular}




\begin{tabular}{|c|c|c|c|}
\hline \multirow{4}{*}{} & \multirow{4}{*}{} & Gentianales & 1 \\
\cline { 3 - 4 } & & Hippuridales & 1 \\
\cline { 3 - 4 } & & Lamiales & 1 \\
\cline { 3 - 4 } & & Myrtales & 1 \\
\cline { 3 - 4 } & Nymphaeales & 1 \\
\hline Polypodiophyta & Polypodiopsida & Salviniales & 3 \\
\hline Equisetophyta & Equisetopsida & Equisetales & 1 \\
\hline Усього & - & - & 41 \\
\hline
\end{tabular}

У межах Magnoliophyta домінує клас Liliopsida, частка якого за видовим складом $83.8 \%$, тоді як на клас Magnoliopsida припадає тільки $16.2 \%$, співвідношення їх складає 5,2:1.

До перших трьох провідних родин належать Potamogetonaceae, Lemnaceae та

Найбільшою кількістю родів представлені родини Hydrocharitacea, Суреraceae та Lemnaceae ( табл. 2). Родовий коефіцієнт (середня кількість видів в роді) складає 1,35. Найбільшу кількість видів має рід Potamogeton (6), Lemna (3) та Typha (3) (таблиця 3).

Адвентивна фракція представлена у флорі шістьма видами, що складає 14,6 \% від загальної кількості вищих водних рослин, серед яких один археофіт південносхіодноазіатського (Acorus calamus L.) і п'ять кенофітів північно-американського походження ( Azolla caroliniana Willd., Azolla filiculoides Lamark., Elodea Canadensis Michx., Sagittaria latifolia Willd., Vallisneria spiralis L.).

Рідкісні рослини, що охороняються на території всієї України у водотоках КДД представлені трьома видами. Salvinia natans (L.) All. занесена до Червоної книги України (статус - неоцінений), Червоної книги Чорного моря (локально рідкісний), Червоного списку Одеської області (рідкісний вид) та до Бернської конвенції.

Nymphoides peltata (S.G.Gmel.) Kuntze занесений до Червноної книги України (вразливий), Червоної книги Чорного моря (локально рідкісний), Червоного списку
Hydrocharitaceae. Разом вони складають понад третину від загальної кількості видів $36.6 \%$. А перші шість родин складають вже $58,5 \%$, більше половини (кожна з родин Alismataceae, Cyperaceae та Турhaceae представлена трьома видами). Провідні родини водних рослин представлені в таблиці 2 .

Одеської області (вразливий) Trapa natans L. s.1. занесений до Червоної книги України (неоцінений), Червоної книги Чорного моря (вразливий), Червоного списку Одеської області (рідкісний) та до Бернської конвенції. До регіонально рідкісних видів, які охороняються тільки на території Одеської області належать п'ять видів: Lemna gibba L. (вразливий), Bolboschoenus maritimus (L.) Palla (недостатньо вивчений), Najas marina L. (недостатньо вивчений), Potamogeton gramineus L. ( недостатньо вивчений), Typha grossheimii Pobed. ( недостатньо вивчений).

\section{Екологічна структура}

Екологічна класифікація ВBР КДД включає в себе три екотипи, серед яких гідрофіти представлені 23 видами рослин (56.1\%), гелофіти - 12 видами (29.3\%), а гігрогелофіти - лише шістьома (14.6\%). Співвідношення екотипів гідрофіти, гелофіти, гігрогелофіти складає 4:2:1. В їх межах екогрупа вільно плаваючих на поверхні води має найбільшу кількість видів - 9 (22\%), занурені вкорінені - 7(17\%), високо травні, низькотравні гелофіти та гігрогелофіти представлені в рівних частках - по 6 (15\%), видів рослин 3 плаваючим на поверхні води листям -5 (12\%), а найменш 
представлені плаваючі в товщі води - 2 види (4\%).

Серед вищезазначених видів у водотоках дельти до групи реофільних видів, здатних зростати про певній швидкості течії, коливанні рівня води та потребують для свого розвитку високого вмісту кисню належать шість видів. До лімнофільних видів, здатних витримувати замулення, погіршення кисневого режиму та надлишок органічної речовини у воді відносяться теж шість видів. Група болотних видів, здатних витримувати надмірний вміст органічної речовини, значне накопичення відмерлих часток рослин, зниження рівня кисню, збільшення концентрації сірководню та метану представлена також шістьма видами. Співвідношення груп реофільні, лімнофільні, болотні у водотоках КДД складає 1:1:1, або по 33\% на кожну групу.
Серед ВВР присутні два види, здатні витримувати надмірне засолення глікогалофіти, а також чотири види нітрофілів - рослин, які потребують багатого нітратного живлення.

По відношенню до трофічного статусу водного об'єкту один вид належить до олігомезотрофів, п'ять видів мезотрофів, п'ять мезо-евтрофів та вісім - евтрофів.

\section{Географічна структура}

В хорологічному спектрі зональних географічних груп найбільша кількість видів відноситься до плюризональної групи, яка складає 44\% або 18 видів рослин. На другому місці за кількістю видів знаходяться температно-меридіональна та бореосубмеридіональна та групи (в кожній 3 них знаходиться по п'ять видів). На третьому місці борео-меридіональна та температнотропічна групи - по чотири види в кожній (табл. 3.).

Табличя 2.

Систематична структура провідних родин флори

Співвідношення окремих таксономічних категорій флори вищих водних рослин КДД

\begin{tabular}{|c|c|c|c|c|}
\hline \multirow{2}{*}{ Родина } & \multicolumn{2}{|c|}{ Кількість родів } & \multicolumn{2}{c|}{ Кількість видів } \\
\cline { 2 - 5 } & абсол. & $\begin{array}{c}\text { Частка від загальної } \\
\text { кількості, \% }\end{array}$ & абсол. & $\begin{array}{c}\text { частка від загальної } \\
\text { кількості, \% }\end{array}$ \\
\hline Potamogetonaceae & 1 & 3.7 & 6 & 14.6 \\
\hline Lemnaceae & 3 & 11.1 & 5 & 12.2 \\
\hline Hydrocharitaceae & 4 & 14.8 & 4 & 9.7 \\
\hline Alismataceae & 2 & 7.4 & 3 & 7.3 \\
\hline Cyperaceae & 3 & 11.1 & 3 & 7.3 \\
\hline Typhaceae & 1 & 3.7 & 3.3 \\
\hline
\end{tabular}


Адвентивна фракція представлена у флорі шістьма видами, що складає 14,6 \% від загальної кількості вищих водних рослин, серед яких один археофіт південносхіодноазіатського (Acorus calamus L.) і п’ять кенофітів північно-американського походження ( Azolla caroliniana Willd., Azolla filiculoides Lamark., Elodea Canadensis Michx., Sagittaria latifolia Willd., Vallisneria spiralis L.).

Рідкісні рослини, що охороняються на території всієї України у водотоках КДД представлені трьома видами. Salvinia natans (L.) All. занесена до Червоної книги України (статус - неоцінений), Червоної книги Чорного моря (локально рідкісний), Червоного списку Одеської області (рідкісний вид) та до Бернської конвенції. Nymphoides peltata (S.G.Gmel.) Kuntze занесений до Червноної книги України (вразливий), Червоної книги Чорного моря (локально рідкісний), Червоного списку Одеської області (вразливий) Trapa natans L. s.1. занесений до Червоної книги України (неоцінений), Червоної книги Чорного моря (вразливий), Червоного списку Одеської області (рідкісний) та до Бернської конвенції. До регіонально рідкісних видів, які охороняються тільки на території Одеської області належать п'ять видів: Lemna gibba L. (вразливий), Bolboschoenus maritimus (L.) Palla (недостатньо вивчений), Najas marina L. (недостатньо вивчений), Potamogeton gramineus L. ( недостатньо вивчений), Typha grossheimii Pobed. ( недостатньо вивчений).

\section{Екологічна структура}

Екологічна класифікація ВВР КДД включає в себе три екотипи, серед яких гідрофіти представлені 23 видами рослин (56.1\%), гелофіти - 12 видами (29.3\%), а гігрогелофіти - лише шістьома (14.6 \%). Співвідношення екотипів гідрофіти, гелофіти, гігрогелофіти складає 4:2:1. В їх межах екогрупа вільно плаваючих на поверхні води має найбільшу кількість видів - 9 (22\%), занурені вкорінені - 7(17\%), високо травні, низькотравні гелофіти та гігрогелофіти представлені в рівних частках - по 6 (15\%), видів рослин 3 плаваючим на поверхні води листям - 5 (12\%), а найменш представлені плаваючі в товщі води - 2 види (4\%).

Серед вищезазначених видів у водотоках дельти до групи реофільних видів, здатних зростати про певній швидкості течії, коливанні рівня води та потребують для свого розвитку високого вмісту кисню належать шість видів. До лімнофільних видів, здатних витримувати замулення, погіршення кисневого режиму та надлишок органічної речовини у воді відносяться теж шість видів. Група болотних видів, здатних витримувати надмірний вміст органічної речовини, значне накопичення відмерлих часток рослин, зниження рівня кисню, збільшення концентрації сірководню та метану представлена також шістьма видами. Співвідношення груп реофільні, лімнофільні, болотні у водотоках КДД складає 1:1:1, або по 33\% на кожну групу.

Серед ВВР присутні два види, здатні витримувати надмірне засолення глікогалофіти, а також чотири види нітрофілів - рослин, які потребують багатого нітратного живлення.

По відношенню до трофічного статусу водного об'єкту один вид належить до олігомезотрофів, п'ять видів мезотрофів, п'ять мезо-евтрофів та вісім - евтрофів.

\section{Географічна структура}

В хорологічному спектрі зональних географічних груп найбільша кількість видів відноситься до плюризональної групи, яка складає 44\% або 18 видів рослин. На другому місці за кількістю видів знаходяться температно-меридіональна та бореосубмеридіональна та групи (в кожній з них знаходиться по п'ять видів). На третьому місці борео-меридіональна та температнотропічна групи - по чотири види в кожній (табл. 3.). 
Географічна структура ареалів видів ВВР КдД

\begin{tabular}{|c|c|c|c|c|c|}
\hline Зональне поширення & абс. & $\begin{array}{c}\text { Регіональне } \\
\text { поширення }\end{array}$ & абс & $\begin{array}{c}\text { Океанічно- } \\
\text { континентальне } \\
\text { поширення }\end{array}$ & абс. \\
\hline плюри зональний & 18 & циркумполярний & 18 & евриконтинентальний & 2 \\
\hline борео-субмеридіональний & 5 & євразійський & 8 & евриокеанічний & 14 \\
\hline $\begin{array}{c}\text { температно- } \\
\text { субмеридіональний }\end{array}$ & 5 & космополіт & 8 & \multirow{5}{*}{ індиферентний } & \multirow{5}{*}{25} \\
\hline борео-меридіональний & 4 & євросибірський & 4 & & \\
\hline температно-тропічний & 4 & \multirow{3}{*}{$\begin{array}{c}\text { євро- } \\
\text { північноамерикан- } \\
\text { ський }\end{array}$} & \multirow{3}{*}{3} & & \\
\hline $\begin{array}{c}\text { субмеридіонально- } \\
\text { меридіональний }\end{array}$ & 3 & & & & \\
\hline борео-температний & 1 & & & & \\
\hline
\end{tabular}

В хорологічному спектрі регіональних груп найбільше представлені види 3 циркумполярним поширенням - 18 видів (44\%). Друге місце поділяють види, що мають космополітне та євразійське поширення - їх по вісім. На третьому місці євросибірське поширення, яке представляють чотири види. А найменше видів євро-північноамериканського поширення, три види, які є адвентивними для флори України - A. caroliniana, A. filiculoides, S. latifolia

По відношенню до океанічності та континентальності, то найбільший вклад у флору вносить група індиферентна до континентальності та океанічності - 25 видів (61\%). Надають перевагу океанічним регіонам 14 видів. А ось континентальним регіонам надають перевагу тільки два види.

Характерною особливістю водної флори водотоків Кілійської дельти Дунаю $є$ широке розповсюдження ареалів видів, які часто охоплюють майже всі зони рослинності, пояси та регіони континенту.

Нижче представлений анотований список вищих водних рослин водотоків КДД 3 вказанням екологічних характеристик та поширення їх ареалів.
Анотований список вищих водних рослин водотоків КДД

Acorus calamus L. Гігрогелофіт (Гг); apx., пд. та пд.-сх. Походження; темп.субмер., циркумп., індиф.

Alisma plantago-aquatica L.

Низькотравний гелофіт(НГ); плюриз., євраз., індиф.

Azolla caroliniana Willd. Вільноплаваючий на поверхні води (ВП); кен. пнамерик. походження; субмер.- мерид., європівнічнонамер., евриокеан.

Azolla filiculoides Lamark. ВП, кен. пн.америк. походження; субмер.-мерид., європівнічноамерик., евриок.

Bolboschoenus maritimus (L.) Palla. Гг; бор.-мерид., циркумп., евриконт., глікогалофіт .

Butomus umbellatus L. НГ; бор.-мерид., євраз., індиф., реофіл.

Ceratophyllum demersum L. ВП; плюриз., космоп., індик., болотний, евтроф.

Eleocharis palustris (L.) Roem. Et Schult. Гг; плюриз., циркум., індиф.

Elodea canadensis Michx. Занурений вкорінений (3); кен. пн-америк. походж.; плюриз., косм., індиф., лімнофіл, мезотроф.

Equisetum fluviatile L. НГ; бор.-субмер., циркумп., індиф., мезотроф. 
Glyceria maxima (C. Hartm.) Holmb. Високотравний гелофіт (ВГ); бор.-субмер., циркумп., евриок.

Hydrocharis morsus-ranae L. ВП; бореомеридіональний, євразійський, індиферентний; евтроф.

Iris pseudacorus L. Гг; бор.-мерид., євросиб., індиф.

Lemna gibba L. ВП; температ.-троп., циркум., евриок.; нітрофіл.

Lemna minor L.BП; плюриз., космоп., індиф.; болотний, нітрофіл, евтроф.

Lemna trisulca L. Вільно плаваючий в товщі води (ВТ); плюриз., циркумп., евриок., болотний, нітрофіл, мезо-евтроф.

Mentha aquatica L. Гг; плюриз., космоп., індиф.

Myriophyllum spicatum L. 3; плюриз., циркумп., індиф., лімнофіл, евтроф.

Najas marina L. 3; темпер.-троп., циркумп., індиф.; глікогалофіт, мезо-евтроф.

Nymphoides peltata (S.G. Gmel) O. Kuntze. 3 плаваючим на воді листям (ЗПЛ); темп.-субмерид., євраз., індиф.

Oenanthe aquatica (L.) Poir. Гг; плюриз., євраз., індиф.

Phragmites australis (Cav.) Trin. Ex Steud. ВГ; плюриз., косм., індиф., лімнофіл.

Potamogeton crispus L. 3; плюриз., циркумп., евриок., реофіл, мезо-евтроф.

Potamogeton gramineus L. ЗПЛ; бор.темп., циркумп., індиф, оліго-мезотр.

Potamogeton natans L. ЗПЛ; бор.субмер., циркумп., індиф., лімнофіл.

\section{ОБГОВОРЕННЯ}

Домінування класу Liliopsida $\epsilon$ характерним як для водних флор загалом, так i для окремих водних флор України $[17,20$, 9]. Згідно перефразованого «загального закону» Декандоля - чим бідніше флора, тим менша кількість родин містить половину іiі складу[22], а оскільки перші шість родин складають понад 50\% видового складу, то водну флору водотоків КДД можна характеризувати як бідну флору.

За кількістю видів домінує Potamogetonaceae, що $\epsilon$ характерним для
Potamogeton nodosus Poir. ЗПЛ; плюриз., циркумп., евриок.

Potamogeton pectinatus L. 3; плюриз., косм., індиф.; лімнофіл, евтроф.

Potamogeton perfoliatus L. 3; плюриз., косм., індиф.; реофіл, мезотроф.

Sagittaria latifolia Willd. НГ; кен. пн.америк. поход.; темпер.-субмер., європівнічноамерик., евриок.

Sagittaria sagittifolia L. НГ; плюриз., євраз., індиф., реофіл, мезотроф.

Salvinia natans (L.) All. ВП; темпер.мерид., євраз., евриок., евтроф.

Scirpus lacustris L. ВГ; плюриз., євросиб., евриок.; реофіл, мезо-евтроф.

Spirodela polyrrhiza (L.) Schleid. ВП; плюриз., косм., індиф., болотний, евтроф.

Sparganium erectum L. НГ; бор.субмер., євросиб., індиф.; реофіл, мезотроф.

Stratiotes aloides L. ВП; бор.-субмер., євросиб., індиф., болотний.

Trapa natans L.S.L. ЗПЛ; темпер.субмер., циркумп., евриок., мезо-евтроф.

Typha angustifolia L. ВГ; темпер.субмер., циркумп., евриок., лімнофіл.

Typha grossheimii Pobed. ВГ; субмер.мерид., євраз., евриконт.

Typha latifolia L. ВГ; плюриз., циркумп., індиф., болотний, нітрофіл.

Vallisneria spiralis L. 3; темпер.-троп., циркумп., евриок.

Wolffia arrhiza (L.) Horkel ex Wimm. BП; темпер.-троп., циркумп., евриок., евтроф.

водних флор України та інших Свразійських флор [5, 19], проте не є характерним для водної флори світу, де найбільш репрезентованою $є$ родина Podostemaceae [19]. Порівняння з водними флорами інших регіонів показало, що подібний спектр провідних родин мають флори різних водних об'єктів та різних областей України, наприклад в основних водотоках Національного природного парку «Подільські Товтри», в Харьковській області 
та в техногенних озерах малого Полісся [14, 20,9]

Мала частка гігрогелофітів не $\epsilon$ характерною для водної флори [19] і у водотоках КДД обумовлена пониженими елементами рельєфу, внаслідок чого береги практично відсутні, грунти зазнають постійного підтоплення, утворюючи плавні. Флора цих ділянок (або плавнів) представлена,переважно представниками гелофітів.

За вимогами до трофічних умов найбільша кількість видів відноситься до категорії евтрофні, також значна частка

\section{ПІДСУМОК}

Було встановлено, що видове багатство макрофітів водотоків КДД нараховує 41 вид, які відноситься до 27 родів, 21 родин, 16 порядків, 4 класів та 3 відділів. Виявлені характерні для даної флори (знижена, порівняно 3 іншими флорами кількість представників родини (yperaceae) та спільні 3 іншими євразійськими водними флорами (переважання класу Liliopsida, родини Potamogetonaceae та роду Potamogeton) риси. Визначено екологічну структуру та іï

\section{Лimepamypa}

1. Bioriznomanitnist' Dunays'koho biosfernoho zapovidnyka, zberezhennia ta upravlinnia(1999). Pid red. Sheliah-Sosonko Yu.R. Kyiv: Naukova dumka.

2. Borsukevych L.M. Structural and comparative analysis of aquatic flora of Eastern Galiciya (2009). Chornomors'k. bot. z. 5(1): 80-90.

3. Chappuis E., Gacia E., Ballesteros E. (2014) Environmental factors explaining the distribution and diversity of vascular aquatic macrophytes in a highly heterogeneous Mediterranean region. Aquatic Botany Volume 113:72-82 .

4. Chertkova M.S. The comparative characteristic of Kilia's delta streams by vascular macrophytes (2015). Nauk. zap. Ternop. nats. ped. un-tu. Ser. Biol. 3-4 (64): 713-717.

5. Chernaia G.A. Vysshaia vodnaia flora basseyna reki Severskiy Donets (1982). Kiev.

6. Dubyna D.V., Geyny S., Groudova Z. i dr. Makrofity - indikatory prirodnoy sredy (1993) Kiev.:Nauk. dumka. мезотрофних та мезо-евтрофних видів, що свідчить про високий вміст біогенних речовин у водотоках КДД.

Формування сучасної флори водотоків КДД відбувається за рахунок широкоареальних видів - плюризональних , циркумполярних, індиферентних до континентальності та океанічності, що, в цілому, збігається, з хорологічним спектром водної флори України та є характерним для флор різних регіонів помірної зони Євразії [7, 22].

особливості - переважають вільно плаваючі на поверхні види (22\%), занурені вкорінені (17\%), а також високотравні, низькотравні гелофіти та гігрогелофіти - по 15\%. У географічній структурі за зональним поширенням переважають представники плюризональної групи $\quad(44 \%), \quad$ за регіональним - циркумполярної (44\%), а за континентальністю-океанічністю індиферентні (61\%).

7. Dubyna D.V., Sheliah- Sosonko Yu.R. Heohrafichna struktura flory vodoym Ukrainy (1984) Ukr. botan. zhurn. 41(6): $1-7$.

8. Dubyna D.V., Shelyag-Sosonko Yu.R., Zhmud O.I., et al. Dunaisky Biosphere Reserve. Plant Kingdom. (2003) Kyiv: Phytosociocentre.

9. Dubyna D.V. Strukturno-porivnial'nyy analiz flory radians'koi terytorii dolyny richky Dunaiu (1990). Ukr. botan. zhurn. 47(4): 16-20.

10. Fedorchuk I.V., Kozak M.I.. Systematychnyy analiz doslidzhenykh vydiv makrofitiv-indykatoriv osnovnykh vodotokiv Natsional'noho pryrodnoho parku "Podil's'ki Tovtry" (2015). Visnyk Cherkas'koho universytetu. Seriia "Biolohichni nauky". 335 (2): 116 120.

11. Janauer, G. A. (2003). Methods. Archiv für Hydrobiologie 14(1-2): 9-16.

12. Karpova H., Zub L., Mel'nychuk V., Protsiv H. Otsinka ekolohichnoho stanu vodoym metodamy bioindykatsii. Pershi kroky do otsinky iakosti vody (2010) Berezhany. 
13. Meusel H., Jager E., Weinert E. Vergleichende Chorologie der zentral eutopaischen Flora (1965) Jena: Fischer.

14. Mironova N.H. Vyshchi vodni ta pryberezhnovodni roslyny tekhnohennykh ozer Maloho Polissia. Naukovyy visnyk NLTU Ukrainu. 22 (6): 63-67.

15. Mosyakin S. L., Fedoronchuk M. M. Vascular plants of Ukraine (1999). A nomenclatural checklist. Kiev: M.G. Kholodny Inst. of Botany NAS of Ukraine.

16. Official lists of regional rare plants of administrative territories of Ukraine (reference book) (2012). Compiled by Prof., Dr. Tetyana L. Andrienko, Dr. Mykyta M. Peregrym. Kyiv: Alterpress.

17. Papchenkov V.G. (2003) O klassifikatsii rasteniy vodoemov i vodotokov. Gidrobotanika: metodologiia, metody: Materialy shkoly po gidrobotanike. Rybinsk, p. 23-28.

18. Papchenkov V.G. Rastitel'nyy pokrov vodoemov i vodotokov Srednego Povolzh'ia (2001). Iaroslavl': TsMP MUBiNT.
19. Raspopov I.M., Papchenkov V.G., Solov'eva V.V. Sravnitel'nyy analiz vodnoy flory Rossii i mira (2013). Izvestiia Samarskogo nauchnogo tsentra Rossiyskoy akademii nauk. 13 (1): 16-27.

20. Rokitianskiy A.B., Gamulia Yu.G. Flora sosudistykh vodnykh rasteniy Khar'kovskoy oblasti (annotirovannyy spisok i osnovnye parametry) (2017). Fitoraznoobrazie Vostochnoy Evropy. - 10 (1): 14-35.

21. Sheliag-Sosonko Yu.R., Dubyna D.V.(1984) Gosudarstvennyy zapovednik "Dunayskie plavni". Kiev: Nauk. Dumka.C..

22. Shums'ka N. Flora vodoym m. IvanoFrankivs'k (2004). Visnyk Prykarpats'koho universytetu. Biolohiia. 4:36-42.

23. Sviridenko B.F. Flora i rastitel'nost' vodoemov Severnogo Kazakhstana (2000) Omsk.

24. Tolmachev A.I. Metody sravnitel'noy floristiki i florogeneza (1986). Novosibirsk:Nauka.

UDC [581.93:581.526.3:556.53](282.243.705)

\title{
THE WATER FLORA STRUCTURE OF THE DANUBE KILIA DELTA WATERCOURSES
}

\author{
M.S. Pohorielova
}

The article deals with the results of the structural-comparative analysis of taxonomic, ecological and geographical structure of watercourses flora of the Kiliya Danube Delta. The list of the aquatic plants consists of 41 species from 27 genera, 21 families, 16 orders, 4 classes and 3 divisions. The analysis of the taxonomic composition of the main taxonomic units and the relationship between them showed that the Magnoliophyta division predominates $(90.2 \%)$ there and the class Liliopsida dominates $(83.8 \%)$ within the former. The first three leading families include Potamogetonaceae, Lemnaceae and Hydrocharitaceae, which make up $36.6 \%$ of the total flora. The flora consists of six adventive species, one of them is archeophyte (Acorus calamus L.) and five are kenophytes (Azolla caroliniana Willd., Azolla filiculoides Lamark., Elodea canadensis Michx., Sagittaria latifolia Willd., Vallisneria spiralis L.). Rare plants, which are protected throughout Ukraine in watercourses, are represented by three species: Salvinia natans (L.) All., Nymphoides peltata (S.G.Gmel.) Kuntze and Trara natans L. s.l. Regional rare species, which are protected only in the Odessa region. include five additional species: Lemna gibba L. (vulnerable), Bolboschoenus maritimus (L.) Palla (insufficiently studied), Najas marina L. (insufficiently studied), Potamogeton gramineus L. (insufficiently studied), Typha grossheimii Pobed. (insufficiently studied).

The investigated ecological structure is represented by three ecotypes, among which the largest number of hydrophytes comprises 23 species $(56.1 \%)$. It is dominated by an eco group of biofilms on the water surface (22\%). The ratio of ecotypes of hydrophytes, helophytes, hygrohelophytes is $4: 2: 1$.

In the chorological spectrum of zonal geographical groups, the largest number of species belongs to the plurizonal group -18 species (44\%). Among the regional groups, a circumpolar distribution that is characteristic of 18 species (44\%) predominates. By the nature of the distribution of species in oceanic or inland waters, the largest number of species belongs to the group indifferent to continentality and oceanicity. A similar spectrum is characteristic of the aquatic flora of Ukraine and other flora of the different Eurasia temperate zone regions.

Key words: taxonomic, ecological, geographical structure, higher aquatic plants, watercourses, Kiliya Danube Delta.

Стаття надійшла 16. 11.2020 р. Рекомендована до друку на засіданні редакиійної колегї̈ після рецензування 